\title{
The Mystery of Wealth and the Role of Divinities: The Economy in Pre-Modern Japanese Fiction and Practice
}

FABIO RAMBELLI

University of California, Santa Barbara rambelli@eastasian.ucsb.edu

Keywords: Buddhist economics, Buddhist literature, merit-making, general economy, Buddhist and Shinto relations, Buddhist temple economic activities

DOI: https://dx.doi.org/10.15239/hijbs.02.02.06

Abstract: This article presents an overview of the economic dimensions of premodern Japanese Buddhism-both economic ideas and activities-by focusing on representative primary sources and important secondary scholarship. It opens with a discussion of economic activities in which temple-shrines and their personnel were directly engaged in. Next, in order to find some type of theorization for those practices, it examines a number of popular stories from medieval and early modern Japan (some of which are still circulating today as children's tales) that deal with the origin of wealth. It problematizes their underlying economic thought, including examples of resistance to dominant ideas about production and wealth. Finally, the paper offers some considerations on the 'general economy' of premodern Japanese Buddhism. 
Quddhist institutions were important economic hubs in medieval Band early modern Japan, as in other Buddhist countries. Still, it is somewhat surprising that normative canonical texts do not offer any specific teachings about the economy beyond superficial considerations about generosity, merit-making, and karmic retribution. One must look instead at specific economic practices and texts elucidating them (narratives, legal documents, etc.) - materials that were part of the 'practical canon' of Buddhism. There we see that at least some segments of premodern Japanese society tried to explain the origin of wealth in terms of the conceptual apparatus provided by Japanese vernacular Buddhist doctrines about local deities (kami). Agricultural production, financial interests, commercial profit, even gambling: all these activities involved the production of something out of nothing. This was explained in terms of the intervention of buddhas and kami in the economic processes; divinities were thus at the center of productive and commercial activities.

This article presents an overview of the economic dimensions of premodern Japanese Buddhism-in terms of both economic ideas and activities-by focusing on representative primary sources and important secondary scholarship. It opens with a discussion of economic activities in which temple-shrines and their personnel were directly engaged in. Next, in order to find some type of theorization for those practices, it examines a number of popular stories from medieval and early modern Japan (some of which are still circulating today as children's tales) that deal with the origin of wealth. It problematizes their underlying economic thought, including examples of resistance to dominant ideas about production and wealth. Finally, the paper offers some considerations on the 'general economy' of premodern Japanese Buddhism. ${ }^{1}$

1 Because of its nature as a preliminary outline of issues that are overall little understood, some readers might find this article oversimplified and underdocumented. It is indeed a summary of research I have conducted over many years, and space prevents me from providing more extensive background and references. Nevertheless, I hope that this general picture of Japanese Buddhist economics, however simplified, will stimulate further investigations. 


\section{Buddhist Economic Practices}

One of the best descriptions of the economic impact of Buddhism in any society is still Jacques Gernet's classic book on Buddhism in medieval China, originally published in 1956, entitled Buddhism in Chinese Society. Gernet strongly criticizes Buddhism for being both an economic burden on the masses and a capitalistic enterprise. He talks about the 'cost of Buddhism to China', such as 'the appalling misery for the peasant class'2 that Buddhism created; 'the imbalance between production and consumption caused by the Buddhist movement' and the 'fiscal problems caused by Buddhism'. ${ }^{3}$ In his treatment, Gernet takes at face value the positions expressed by Chinese medieval anti-Buddhist state officials (and, perhaps, also those of contemporary Maoism) and reiterates their arguments.

In short, Buddhism is presented as a burden for the state because it reduced manpower (monks were unproductive) and tax revenue (monasteries were tax-exempt), thus causing a huge depletion of state wealth (as resources were deflected into Buddhist-related unproductive expenditures). In this way, Buddhism was a harm to the state and the peasants. It is worth noting here that these old Confucian arguments were rehashed in Korea first and later in Japan during the Edo period by anti-Buddhist authors and groups, and contributed to various anti-Buddhist policies from the mid-1600s culminating in the Meiji persecutions (1868-1871). ${ }^{4}$

Still, Gernet also tells us a different story, albeit in a fragmentary and almost surreptitious way. Aside from the fact that state officials and their families were engaged in huge and useless expenses for themselves ('embroidered garments', 'kitchen stoves', 'makeup's), we get the sense that Buddhist institutions were also important economic hubs. They hired a significant amount of labor, both skilled and unskilled; purchased a vast array of different materials, goods,

\footnotetext{
2 Gernet, Buddhism in Chinese Society, 14.

3 Gernet, 30.

4 See Ketelaar, Of Heretics and Martyrs.

5 Gernet, Buddhism in Chinese Society, 36.
} 
and services (materials and goods which had to be produced for and delivered to the temples, thus involving other professional services); ${ }^{6}$ and reclaimed and developed non-cultivated lands; $;^{7}$ Buddhist temples were even involved in supporting the state's colonization endeavors. ${ }^{8}$ In addition, temples were 'industrial installations' (they operated mills, presses, etc.); ${ }^{9}$ commercial and financial centers: 'craft and commerce for the supply of devotional objects in the vicinity of monasteries'; ${ }^{10}$ 'the great monasteries too had shops in the marketplaces [...]. These served, it seems, at once as inns for travelers, as

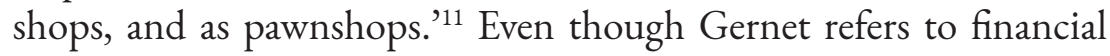
activities with the derogatory word 'usury', no other agencies at the time gave any amount of loans to all kinds of people; if nothing else, loans could be an incentive for entrepreneurship that no state agency would support.

Gernet also does not say that the peasants would have been taxed anyway, and the resources extracted from them would have gone, not to temples-and through them, at least in part, back to their communities-but to the imperial bureaucracy and the military. He also does not emphasize enough that temples did provide services for the population that the state was unable or unwilling to provide: among other things, education, health, technological innovation, and economic support. His focus on the 'cost' of religious institutions ignores that these 'costs' involved attracting workers and trades in the areas around the temples, wages being paid to workers and professionals, and a general diffusion of economic benefits in those areas.

The picture described by Gernet does not seem to have been unique to China. In medieval and early modern Japan, temples were also hubs of innovative economic activities. They served as catalysts for marketplaces, centers of professional guilds, places for entertain-

\footnotetext{
6 For a detailed example, see Gernet, Buddhism in Chinese Society, 18-19.

Gernet, 119.

8 Gernet, 98-100.

9 Gernet, 142.

10 Gernet, 167.

11 Gernet, 168.
} 
ment and performing arts, entrepreneurial agencies involved in land reclamation and agricultural development, technological and industrial innovation, financial activities, trade (including foreign trade until the early seventeenth century). This is true even in the Edo period, a time generally considered as one of decline for Buddhism. Indeed, it is well possible that images of decline and degeneration of Buddhism were artfully spread by authors and groups who were keenly aware of the wealth and economic power of Buddhist institutions and had a direct or indirect interest in appropriating them. ${ }^{12}$

Contrary to received assumptions, Buddhism has never been a world-denying religion, unconcerned with, or clearly inimical to, economic activities. On the contrary, Buddhist practice has always been predicated upon a decent living, as is clear in the case of merit-making, with its goal of improving material life in the present as a way to gain security, peace of mind, and therefore the leisure to engage in Buddhist practice.

Despite the massive economic presence of Buddhist institutions and their entrepreneurial role, the scarcity of theoretical discourses about the economy and economics in canonical literature is astonishing. Wealthy patrons of the Buddha and his Samgha such as Vimalakirti are extolled for their generosity, but the source of their wealth is never explained in detail. An account of the origin of social and economic differences is included in the Aggañna suttanta and other later sources; this is uncannily Marxian in its description of the process that led to the formation of private property, primitive accumulation, and labor division and class/caste distinction. It is however

12 It should perhaps be mentioned, in this context, that Buddhist institutions in Southeast Asia (Sri Lanka, Burma, Thailand, etc.) seem to have been much less entrepreneurial than their East Asian counterparts. As Steven Collins has shown, Sri Lankan Theravada social ideology was rooted in, and promoted, a land-based subsistence economy and its social relations-an economy of stasis and poverty that resisted innovation and change (see Collins, Nirvana and Other Buddhist Felicities). It is perhaps no accident that the most lucrative economic activities in Southeast Asian Buddhist countries were taken over by foreigners-Muslims, Europeans, and Chinese. 
doubtful that this sutra had any direct impact on Buddhist social practices at large; perhaps, it pointed to a need to curb what it sees as socially degenerate practices through the establishment of alternative social and political systems for the Sangha. ${ }^{13}$

The lack of canonical sources on economic matters should not be interpreted as an indication that the latter were not important for monastic communities or temple organizations; rather, it suggests that much of Buddhist economic knowledge was developed in other sources and contexts, what we could call 'practical canon'-a set of teachings, instructions, and rules about practical, everyday matters, that were not addressed in canonical sources. ${ }^{14}$

It is thus necessary to examine actual economic practices at temples and the documents that described them for clues regarding the principles behind them. Economic issues became a primary concern for Buddhist institutions in Japan from the tenth century when, as a consequence of social and political transformations, the centralized state modeled on the Chinese empire began to collapse; temples lost state support and needed to secure new forms of income in order to survive. Over a span of four hundred years, they focused on four main areas: real estate, with the acquisition of land-holdings and their revenues, finance (donations of various nature, investments, levies, and so forth), technology (the creation and control of professional guilds, engineering and infrastructures, transportation); and trade (with some temples hosting regular market places and in some cases even financing risky but lucrative international trade with China). They also needed to come up with marketing strategies and campaigns to promote themselves in competitions with other sacred sites; for that purpose, they relied on a vast array of itinerant religious specialists (bijiri 聖, yamabushi 山伏, jinin 神 人, oshi お師, etc.), who spread teachings and information about temples and shrines and promoted pilgrimages and donations in increasingly large areas of Japan. Some of these specialists (particularly the jinin, affiliated with the large temple-shrine complexes of Nara

13 See Rambelli, 'The Vicissitudes of the Mahāsammata in East Asia'.

14 I owe this notion to Adam Krug. 
and Kyoto, and the yamabushi) were also in charge of collecting tithes and fees.

Finally, we must emphasize a crucial point: Buddhist institutions relied heavily on their 'Shinto' components for both theoretical aspects and practical dimensions of their economic activities; this aspect deserves some background explanation. Between the twelfth and sixteenth centuries, the period primarily discussed in this paper, what are now Shinto shrines were either full-fledged Buddhist temples (dedicated to deities such as Hachiman 八幡, Tenman Tenjin 天 満天神, Konpira 金毘羅, etc.) or parts of large institutions dominated by Buddhist temples, and a significant number of monastics and other religious personnel were in charge of kami matters (theoretical discourses, rituals, administration, proselytism, etc.). ${ }^{15}$ It was natural for such institutions to develop discourses about the economy centered on traditional, local practices and beliefs.

\section{Sacred Properties (butsumotsu 仏物, shinmotsu 神物) and the Origin of Wealth}

From around the eleventh century, religious institutions began to deal with the lack of public funding by accumulating land estates. By the late Kamakura period (later thirteenth century), a new legal principle had gained wide recognition, according to which land donated to buddhas and kami cannot be returned to human ownership (butsuda senyū no chi kuikaesubekarazu 仏陀施入/地不可悔返). ${ }^{16}$ This principle was originally stressed by religious institutions, but later even donors recognized it explicitly. ${ }^{17}$

Religious institutions levied tributes from their estates-mostly rice, but depending on the area, also other products (salt, silk, cotton, metal, dried fish, and so forth). A portion of those tributes, known

15 For a general overview of premodern Japanese assimilation between Buddhism and Shinto, see Teeuwen and Rambelli, eds., Buddhas and Kami in Japan.

16 Kasamatsu, 'Butsuda senyū no chi kuikaeshibekarazu'.

17 Amino, Muen, kugai, raku, 213. 
as hatsubo 初穂 ('first produce') or jōbun 上分 ('superior portion'), was offered directly to the main deity of the temple or shrine as a sign of gratitude for the harvest. This practice was probably connected to ancient customs of the Japanese archipelago. The first produce was offered to the gods (kami) and their emissaries-the local leaders-to thank them for their generosity and to secure their benevolence in the future. Particularly important in this respect were the nie 䞇, first produces (rice and delicacies from the mountains and the sea) offered to the emperor since ancient times. ${ }^{18}$ First produces offered to the kami were stored in sacred storehouses managed by the leaders of the community or by special personnel (the kugonin 供御人) at the imperial household. The following year, those rice grains were loaned to the peasants for sowing (tanemomi 種籵); after the harvest, the peasants would return the amount of grains they had borrowed with a fee-an additional offering to the kami as a sign of gratitude in the form of first produces. ${ }^{19}$ In this way, the kami were envisioned as the source of rice-and therefore, life and wealth-in a cyclical movement requiring human offerings to ensure a bountiful harvest and sustain life. ${ }^{20}$ This cycle is the origin of the practice of lending grains known as suiko 出挙. Under the Ritsuryō 律令 legal system (early 700s-late 900s), suiko was mostly controlled by the state (kusuiko 公 出挙 or public suiko), and provincial governors were the responsible for the loan of seeds preserved in public storehouses; however, there were also private rice-lenders (shisuiko 私出挙). ${ }^{21}$

Around the early eleventh century, when the state was no longer able to enforce public suiko lending, influential religious institutions such as the Grand Shrines of Ise, Hie shrine, and Kumano took control over this ancient custom related to offering hatsubo to the kami,

18 According to historian Ishimoda Shō 石母田正 (1912-1986), the first produce ( hatsubo), especially rice (tanemomi 種籵) had a ritual and sacred nature, and were offered to the local deities and the clan leaders (Ishimoda, Nibon no kodai kokka, 359-61).

19 See Oda, 'Kodai-chūsei no suiko'.

20 Nakazawa, Akutōteki shikō, 23.

21 Amino, Nibon chüsei ni nani ga okita ka, 55-58. 
and gave it new meaning and social relevance. The rice they received as 'superior portion' of the harvest (jöbun), as the 'first produces' began to be called, were considered inalienable sacred properties belonging to kami and buddhas (respectively, shinmotsu 神物 and butsumotsu 仏物) of the temple or shrine owning the land. ${ }^{22}$ The 'superior portion' was then loaned at an interest (kashiage 貸上) to farmers for sowing also outside of their own estates by specialists affiliated with Kumano (yamabushi), Hie (jinin), and Ise (oshi). Gradually, their activities extended from the Hokuriku region in north-central Japan to Kyushu; in contrast, their activities in Kantō and beyond in eastern Japan are recorded only from the Muromachi period (the reason for this regional discrepancy is not clear). After harvesting, the peasants would return to the temple or shrine, as part of the community's annual tributes (nengu 年貢), the amount of rice they had received the previous year plus interests ranging from fifty percent to one hundred percent.

In this way, financial activity took the form of a loan of properties belonging to the buddhas and the kami which, after completion of the agricultural cycle, were returned to the divinities with an additional offering as a token of gratitude (what functioned in fact as interests). In this way, tributes and loan interests were considered as merit-making offerings to the buddhas and the temples. At this stage, the cycle connecting production, sacred offerings, and lending already existed at the intersection of several symbolic layers: ancient local practices related to production and offerings, centralized state taxation, Buddhist appropriation in terms of merit-making; this was carried out in practice by personnel affiliated to 'Shinto' components of large institutions.

Gradually, the concepts of 'first produce' and 'superior portion' was extended to other forms of taxation, such as levies and fees on the commodities transported by merchants when passing through toll posts controlled by religious institutions. Religious interests in the form of 'superior portions' were collected not only in rice, but also in salt (jöbun'en 上分塩), silk, fish, and other products. From

\footnotetext{
22 Kasamatsu, 'Butsumotsu, sōmotsu, ninmotsu'.
} 
the Kamakura period onward, marketplace fees and transit fees (kanshoryō 関所料), which religious institutions charged to itinerant merchants, were also understood as a kind of 'first produce' (batsubo) of trade. ${ }^{23}$ Medieval historian Amino Yoshihiko 網野善彦 argued that such fees developed from offerings made to the deities when travelers crossed sacred thresholds, such as mountain passes, borders, wades, ports, and so forth, or even when traveling by sea (in ancient folklore the sea was often described as closely related to the other world). ${ }^{24}$ According to Amino, this could explain why the responsibility for collecting such fees fell on religious specialists such as kanjin shönin 勧進上人, hijiri and jinin in general. In addition, we should also note that money loaned by Zen 禅 and Ristu 律 temples, known as shidō maisen 祠堂米銭, was granted a special legal and economic status in medieval Japan as 'properties of the Buddha' (butsumotsu). ${ }^{25}$ Sacred loans (suiko) represented the basis of the way in which medieval Japanese society symbolized financial activity.

Amino Yoshihiko further suggested that places where economic and financial transactions occurred, variously called muenjo 無縁 所 (places severed from secular ties) and kugaidera 公界寺 (open temples), were considered separate from the secular world and had sacred features. Markets were located in places that were symbolically envisioned as the margins of the ordinary world: riverbanks, beaches, areas between mountains and plains, sites where a rainbow suppos-

23 In 1535 the Ōyamazaki 大山崎 jinin affiliated with Iwashimizu Hachimangū 岩清水八幡宮 shrine-temple called the toll (niwazeni 庭銭) they charged 'first produce of oil business' (abura shōbai no hatsuwo 油商売ノ初穂). In addition, several other medieval documents mention 'superior portions' (jōbun) related to fish and birds, cloths, sake. In addition, transit fees charged by Nachi in Kumano to sailors and boats were also called jöbun, as well as port fees charged by Mt. Hiko in Kyushu. See Amino, Muen, kugai, raku, 363-64.

${ }^{24}$ On the religious role of the sea in Japan, see Rambelli, 'Sea Theologies: Elements for a Conceptualization of Maritime Religiosity in Japan'.

25 So-called 'pure money' (jozen 浄銭) offered to the buddhas at temples was used for loans (shidōsen) at an interest of one hundred percent a year; see Iwai, Shibonshugi wo kataru, 248-49. 
edly originated-all envisioned as thresholds between this world and the invisible world of kami and buddhas. ${ }^{26}$ According to legal historian Katsumata Shizuo 勝俣鎮夫, it was only in such places that things could acquire the status of commodities and be exchanged or sold for profit. Katsumata argues that markets were places where things were separated from their worldly ties; the seller would give them temporarily to the deities, who in turn would give them to the buyer; in this way, the deities were the center of trade interactions. At the marketplace, then, objects exchanged ceased to be part of a gift economy and became commodities, thus giving birth to commerce. ${ }^{27}$ This would also explain why marketplace fees, charged by supervisors affiliated with religious institutions, were sometimes considered 'first produce'-offerings for the divinities as signs of gratitude. Not only were value and surplus produced by the deities, but their production also occurred in specific places that were considered sacred. In this way, the relation between religion and economy became even stronger. The language of agricultural production was thus used, at least initially, to explain the production of surplus value in trade. However, the origin of wealth in trade could not be fully explained based on agriculture, which was normally conceptualized as a static source of an unchangeable amount of production. As we shall see below, many medieval tales describe the sudden origin of wealth as due to the intervention of some divinity after the protagonist's visit to a marketplace, a temple/shrine, or along the road (which was considered at the time a no-man's land and thus a potential site for supernatural encounters).

Fiction, Wealth, and the Sacred

At least some segments of medieval Japanese society tried to explain (or construct) the 'mystery' of the production of wealth in terms of the conceptual apparatus provided by religious institutions and their

\footnotetext{
26 See Amino, Muen, kugai, raku.

${ }^{27}$ Katsumata, 'Baibai, shichiire to shoyū kannen'.
} 
doctrines. Agricultural production, financial interests, commercial profit, even gambling: all these activities involved proliferation, that is, the generation of something from nothing. ${ }^{28}$ This was explained in terms of the intervention of buddhas and kami in the economic processes. The divinities were at the center of all productive and commercial activities: they generated the crops, and to them the first produce was returned; they generated interests, and they enabled objects to be exchanged for profit; they even controlled the fortune of gamblers. In other words, the intellectual framework of medieval Japanese economy maintained that buddhas and kami bring wealth to this world by intervening directly in the generation of surplus (added value), in agriculture and in any other commercial and manufacturing activities. Part of the surplus they generated was supposed to be returned to them in order to keep the cycle of general economy functioning. In the realm of economics, as well as in the realm of religion, small investments (rice grains) could yield enormous profits when controlled by the deities.

Wealth is described in medieval Japan as the result of the interaction with the Invisible World of gods and spirits-as retribution from some deity for good actions and moral behavior. According to the same logic, the deities would punish immoral behavior with poverty; immoral people would either remain poor or lose their wealth. Wealth was also understood as 'worldly benefits' (genze riyaku 現世利益) in general: long life to the emperor, peace in the realm, regular seasons, bountiful harvests-in other words, political and social order, economic welfare, and good health.

An effective way to understand the status and features of wealth in the medieval Japanese imaginary more in depth is through an analysis of narratives such as setsuwa 説話, otogizoshi 御伽草子, and painted scrolls (emakimono 絵巻物), which were composed by intellectuals and priests and were widely used in sermons and performances of

28 In medieval Europe too, the generation of wealth out of nothing was a major subject of wonder and religious discussion. Particularly interesting in this respect is the way in which the Church defined and treated usury; see Le Goff, Your Money of Your Life. 
a religious nature. The interest of these sources lies in their broad appeal and diffusion, and in the fact that they were produced and circulated for many centuries, thus describing a rather constant episteme; changes in the understanding of economic practices began to emerge in the Tokugawa period, as we will discuss below.

Stories about wealth as karmic retribution for good deeds already appear in the very first collection of Buddhist narratives composed in Japan, the Nibon ryoiki 日本霊異記 (early ninth century); those narratives follow closely textual precedents from China and India, in turn based on Indian Mahayana literature, in which good deeds generate good karmic seeds and are rewarded with material benefits in this life and spiritual blessings in the next. ${ }^{29}$ However, medieval stories expand the range of divinities involved in wealth bestowal and importantly shift their focus on local kami and hybrid Buddho-Shinto gods. This shift had momentous consequences, because it marked the adoption by Buddhist institutions of originally non-Buddhist entities in the definition of economic activities, also as a way to control and theorize secular practices as part of a general economy of the sacred (see the Concluding Remarks).

A well-known story is presented in the Shigisan engi 信貴山縁起, a painted scroll (emakimono) with texts composed in the thirteenth century, which describes three adventures of the priest Myōren 妙蓮 on Mt. Shigi 信貴山一the location of the Chōgosonshiji 朝護孫子 寺 temple-in Kawachi province near present-day Osaka. The first scroll is particularly relevant for our discussion here. The emaki is without text, but the narrative content of the images can be reconstructed from stories appearing, among other sources, in the Uji shiu $i$ monogatari 宇治拾遺物語 (early thirteenth century). ${ }^{30}$ Here I refer to this version, a story entitled 'Shinano no kuni no hijiri no koto' 信 濃国ノ聖ノ事 (About a bijiri from the Shinano province). ${ }^{31}$ Myōren, a priest from Shinano (present-day Nagano prefecture in central Japan), after his ordination at the Tōdaiji 東大寺 in Nara, began to

\footnotetext{
29 See Nakamura, Miraculous Stories from the Buddbist Tradition.

30 Among the latter, see Shigisan engi.

31 In Uji shüi monogatari, Kohon setsuwa-shū, 196-202.
} 
practice austerities and worship Bishamonten 毘沙門天 on Mt. Shigi. Every day, the priest sent his bowl flying to the house of a wealthy villager of humble origins to collect alms. ${ }^{32}$ One day, the family of the wealthy villager did not give alms as usual; instead, they threw the bowl in the storehouse (kura 倉) and locked it inside. Then, the storehouse came flying to Mt. Shigi near where Myōren was praying. The wealthy villager went to the mountain to ask for the restitution of his wealth. The priest kept the building and some rice from it, and returned the rest by using again his magic bowl.

A later version, the tale 'Shigisan' in the collection Shōyoshō 聖誉 抄 (1547), adds the story of how the rich villager initially acquired his wealth and ends with its complete loss. The 'wealthy Yamazaki' (Yamazaki chōja 山崎長者), as this figure is called in this story, was a person of humble origin who succeeded in becoming rich thanks to the intervention of the Buddhist divinity Bishamonten (Sk. Vaiśravana), which in medieval Japan was often envisioned as a protector of economic success. Yamazaki began by accumulating religious virtue (toku 徳) by putting alms into the flying bowl belonging to the priest Myōren of Mt. Shigi; in retribution, Bishamonten intervened and gave him wealth. Here, the unstated implication was that Yamazaki, in order to preserve his newly acquired wealth, should have continued to give alms; the day he stopped, the magic bowl would take away his entire wealth (the storehouse). In other words, wealth is never eternal and stable, in line with the Buddhist worldview based on impermanence.

32 This story is not completely preposterous. The Shugendō 修験道 tradition has a ritual that is supposed to make a bowl fly (bihachi-hō 飛鉢法), in order to bring alms to a practitioner. This ritual has a scriptural basis in the Nyoi bōju tenrin himitsu genshin jöbutsu konrin juō kyō (chapter 'Hōhatsu-bon') This sutra is a typical Tantric text, describing esoteric rituals enabling the practitioner to control agents of the invisible world, in particular the dragon kings, in order to acquire worldly benefits ('wealth' broadly understood) and Buddhahood in the present life. This story also suggests that yamabushi may have been involved in the production and circulation of this type of narratives about the cycle of religious giving and secular wealth. 
Indeed, many years later, Yamazaki's descendants, tired of giving alms every day to the priest, gave him black rice and fish as a sign of contempt. The priest threw away this food and washed his bowl in a river. As a consequence, the storehouse of Yamazaki's descendants flew away to Mt. Shigi; the chöja's family lost everything and became poor again. A similar story, included in the Kohon setsuwash $\bar{u}$ 古本説 話集 (early twelfth century), describes what happened to the wealthy Indian Ruci, who lost everything when he insulted the gods. ${ }^{33}$ In the story of Yamazaki, the affront was made directly to the monk Myōren, but that amounted to an insult to Bishamonten as well.

According to these stories, the accumulation and preservation of wealth require a continuous and incessant effort on the part of the wealthy - not only the individuals (chöja) but also, and crucially, their families. As a sort of contract between one family and a deity, it should never be violated-the penalty being the complete loss of wealth and return to poverty.

However, the question remains as to how wealth is actually accumulated in the first place. Other stories tell us that, first of all, it is necessary to free the house from the 'gods of poverty' (binbogami 貧乏神) and let the gods of good fortune (fuku no kami 福の神) in; only then can the protagonist begin to accumulate wealth. An example of this way of thinking is the otogizosh $i$ 'Umezu no chōja monogatari' 梅津の長者の物語 (The Story of the rich man from Umezu), written between the end of the Muromachi and the beginning of the Edo periods (late sixteenth-early seventeenth centuries).

Sakon-no-jō Tominaga and his wife, who live in the village of Umezu, are very poor but honest and generous. They have deep faith in the god of wealth Ebisu Saburō 夷三郎 and pray that he free them from the 'gods of poverty' and give them wealth. One day Tominaga meets a nun who was lost on the road, and kindly directs her in the right direction. The nun gives him ten coins (sen 銭). Taking it as a gift from Ebisu, he gives the coins to his wife and tells her to buy rice cakes (mochi 餅) to celebrate. On her way home from the market, the wife meets an old man (okina 翁); moved by

33 Kohon setsuwashū, vol. 2: 96-103. 
compassion by the destitute and hungry old man, she gives him the rice cakes she had bought. The old man tells her: 'I will repay you soon' and leaves. That night, the husband and wife have a revelatory dream. The old man appears to them in his real form as the god Ebisu Saburō in person and tells them that he is going to give them wealth. First, however, he must rid their house of the gods of poverty that plague it. The story continues describing the battle between Ebisu and his allies (Inari 稲荷, Bishamonten, and their retinue) and the gods of poverty. At the end of a victorious battle, Ebisu tells husband and wife that, as a retribution for their honesty and faith, he will protect them. All together they held a banquet, attended also by the other gods of fortune (Daikokuten 大黒天, Jurōjin 寿老 人, Fukurokuju 福禄寿, Hotei 布袋). The good deities later defeat a band of robbers who try to assault the new rich couple. Eventually, the two protagonists become servants of an aristocratic family.

In other cases, the divinities can decide to give wealth to someone just as retribution for a simple act of kindness, without the need to engage in battles with other divine entities. A variant of the previous story, diffused all over Japan, involves the bodhisattva Jizō 地蔵. On New Year's Eve, a poor old couple goes to the market to sell straw hats (kasa 傘); it is a cold winter day, and it is snowing. Unfortunately, they are not able to sell anything, and go back home without even the money to buy mochi (rice cakes) to celebrate the end of the year. Along the way, the couple sees a set of six statues of Jizō. They think that the Jizō might be cold in that weather and decide to put the hats on the heads of the statues. Later, Jizo appears to the couple in their house and gives them pieces of gold as retribution for their kindness. In this case, the old couple did not really give up on anything in favor of Jizō, as they had made the hats to sell them at the market so that they could buy mochi to celebrate the New Year; at the end of the market day, the hats remain unsold and are therefore without any immediate value. Still, their kindness and solicitude toward Jizō's statues trigger the bodhisattva's intervention.

As we can see in these stories, one can become rich only upon the intervention of divinities of good fortune. Nevertheless, wealth is usually described as a gift that rewards a long and continuing attitude (honesty, devotion, kindness). Even though some stories tell 
of deities giving a precious gift (gold or in other precious objects) to a poor person or family, still, that gift alone is not sufficient to accumulate and preserve wealth.

One story in particular describes in detail the dynamics of original accumulation-the ways in which wealth is produced and preserved. It is the otogizoshi entitled Daikoku mai 大黒舞 (The Dance of the God Daikokuten), also known as 'Daietsu monogatari' 大悦 物語 (The Story of Daietsu), written between the late sixteenth and the early seventeenth century but based on a story appearing already in the Konjaku monogatarishü 今昔物語集 (early twelfth century). ${ }^{34}$ A certain Daietsunosuke from Yoshino in Yamato province was a deeply filial man. One day, during a pilgrimage to Kiyomizudera 清 水寺 in Kyoto, he saw the bodhisattva Kannon 観音 who told him: 'You are very filial, and the gods want to give you good fortune and long life. I want to give you wealth as well. On your way back home, you will see one blade of rice straw (warashibe 橖芯): pick it up!' He does find it, but when he tries to pick it up, he has to fight an ogre (oni 鬼) who tries to take it away from him. Daietsunosuke eventually succeeds in wrestling the straw away from the ogre. Later, Daietsunosuke exchanges that straw with people he encounters along the way for other objects: first, three pears, then three robes, then a horse, and finally three pieces of gold. Daietsunosuke is now rich. One day, his house is visited by the god Daikokuten, who gives him several gifts: a wish-fulfilling jewel (nyoi hōju 如意宝珠), a magic hammer (uchide no kozuchi, which when used produces everything one desires), and a hat that makes one invisible-concrete symbols of fortune and wealth in the pre-modern Japanese imaginary. Later in the story, the gods of fortune protect Daietsunosuke from the assault of a gang of robbers. In the end, Daetsunosuke marries a 'princess' (a noble lady), the daughter of a court minister; together they have many children and live prosperous.

\footnotetext{
34 Konjaku monogatarishū, fasc. 16 story no. 28.
} 


\section{Considerations}

These stories assume poverty as the original economic condition for their protagonists, who are always poor at the beginning. In the stories, however, there is also an elusive realm of wealth and fortune on the background, associated with the aristocracy in the capital on the one hand and with the divinities in the invisible world on the other hand. The protagonists are only able to acquire wealth as a consequence of divine intervention, which invariably comes as retribution for their good behavior. As Komatsu Kazuhiko 小松和彦 explains, wealth or abundance (tomi 富) is envisioned as a result of good fortune ( $f u k u$ 福), in turn generated by positive divine intervention. There is also a negative divine intervention (yaku 厄 or wazawai 災い), understood as a form of divine punishment (shinbatsu 神罰, tenbatsu 天罰 or butsubachi 仏罰) for evil behavior. ${ }^{35}$ In this sense, abundance and fortune are directly related to religious virtue (toku 徳) and merit-making (kudoku 功徳). ${ }^{36}$ In other words, when a poor person (binja 貧者) accumulates religious merit (toku, kudoku), the deities intervene to bestow upon him (or, more rarely, her) good fortune $(f u k u)$, which results in wealth (tomi). At that point, the protagonist has become rich (choja). According to these stories, then, merit-making generates economic profit; the language of religious virtue overlaps explicitly with that of economics. Wealth, however, is reversible. When the protagonists cease to accumulate religious merit, their wealth also disappears.

FIG. 1 Structure of Buddhist economy

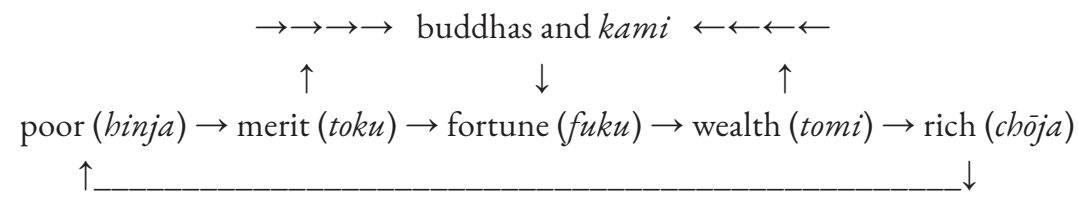

\footnotetext{
35 See Rambelli, 'Buddha's Wrath'.

36 Komatsu, Fuku no kami to binbōgami, 6-10, 90.
} 
Wealth is also the result of religious purification, ${ }^{37}$ expressed in these stories as expelling the gods of poverty and demons who prevent the protagonists from becoming rich. Historical documents suggest that jinin and yoriudo 寄人 were responsible for this kind of wealth-producing purifications, ${ }^{38}$ envisioned as expelling the gods of poverty (binbogami) to let the gods of fortune (fuku no kami) in. A number of divinities in Japanese religions specialize in the production of wealth. In addition to the seven gods of good fortune (shichifukujin 七福神: Daikokuten, Ebisu 恵比寿, Bishamonten, Benzaiten 弁財天, Fukurokuju, Jurōjin, Hotei), which appear as a set towards the end of the Muromachi period and became widely popular during the Edo period, we also find Inari, Kannon, Jizō, and in some cases also Fudō Myōō 不動明王 and Matarajin 摩多羅神. The cult to these deities was actively encouraged by religious institutions, which since the Muromachi period organized popular festivals with performances, sermons, and rituals. ${ }^{39}$

Wealth had to be protected from enemies, described as ogres (oni) or robbers. Many stories seem to imply that wealth in fact belongs originally to the demons, as in the case of Daietsunosuke, who wrestles away the piece of straw from an oni. The protagonists of these stories can accumulate wealth only upon permission by certain deities, who want to reward them for their devotion and morality. In this context, wealth is an ambiguous and potentially dangerous thing: a demonic feature 'domesticated' by Buddhist morality.

Another characteristic of wealth is that it rewards dominant and stereotypical ideas of morality and social behavior: faith and devotion in deities, filial piety, generosity, alms-giving, and pilgrimage to temples and shrines-always by members of the lower strata of society. At the same time, there was the idea that the upper strata of society were such because of their virtue and morality.

As Komatsu Kazuhiko notes, medieval literature offers virtually

37 See Komatsu and Kurimoto, Keizai no tanjö; Komatsu, Fuku no kami to binbōgami.

38 Komatsu, Fuku no kami to binbōgami, 74-75.

39 See Miyata, ed., Shichifukujin shinkōjiten. 
no example of peasants who became rich simply by cultivating their land-or, we may add, because of their entrepreneurship. Komatsu divides stories of enrichment into two main categories: those about finding gold, and those about increasing cultivated lands. However, while the former group deals with the prosperity of the protagonist who is already a choja or becomes one, the latter group recounts stories of failure and final impoverishment. ${ }^{40}$ In other words, wealth is very often described as the result of non-agricultural, mercantile endeavors (trade and industry, with consequent accumulation of capital, expressed in gold, money, or rice); exchange is particularly important for the creation of value, seen here as economic surplus. Significantly, wealth is also presented as a result of divine intervention and magical powers: Daietsunosuke's increasingly profitable exchanges that ultimately yield him three pieces of gold out of the original blade of straw, can be only the result of magic (or of a successful series of imbroglios against gullible people). We see the close connection between wealth and magical operations also in Daikokuten's gifts to Daietsunosuke: in particular, the wish-fulfilling jewel and the magic hammer suggest the capacity to produce unlimited wealth, in the form of precious materials (gold) and precious objects produced out of nothing or through a transformation of ordinary, vile materials.

These stories seem to reflect the development of forms of protocapitalism, especially from the late fourteenth and early fifteenth centuries onward. In some cases, religious institutions or religious groups were active promoters of such new mode of production and generation of wealth; ${ }^{41}$ in other cases, religious institutions were passive followers, attempting to give Buddhist meaning to processes of wealth formation which, in some cases, seemed to go against the fundamental precepts of the religion. As particularly evident in 'Daikoku-mai', wealth accumulated by the protagonist Daietsunosuke

\footnotetext{
40 Komatsu, Fuku no kami to binbōgami, 105.

41 Among religious institutions actively engaged in trade and capitalist ventures, the cases of the Ritsu sect first and Zen sects later are well known. Some temples deprived of land prospered by holding markets and levying fees on trade routes.
} 
results from a series of exchanges, which, while apparently governed by the logic of barter (based on reciprocity and mutual satisfaction of needs, and emphasizing the use-value of the goods exchanged), follow in fact a capitalistic logic of individual profit. While his trading partners seem to be happy with the barters they conclude, as they do need the objects Daietsunosuke offers them (and are willing to get rid of the objects they have as useless), Daietsunosuke is not interested in the use-value of the object he acquires; rather, his goal is pure profit, the accumulation of capital-wealth. In order to reach his goal, he is willing to exchange objects on the basis of an obviously unjust value: after a series of exchanges, one piece of straw ultimately yields three pieces of gold! It is not surprising, then, that the story presents the straw as a potentially demonic thing wrestled away from an oni.

In other words, it seems that to the authors of these stories, and perhaps also to their audience, the actual mechanisms of wealth production were not clear at all. By emphasizing supernatural intervention and magic tricks, and by describing a world of fairy tales (with deities, demons, and princesses), the stories ignore, or willfully misrepresent, the social and economic processes at play. We can probably see here the deeply conservative (if not explicitly reactionary) nature of this kind of narratives. This last point is also clear from another feature of these stories, namely, the fact that they envision the ultimate success of one's wealth acquisition as their protagonists' recognition by the imperial court, in particular in the form of a court title (Daietsunosuke marries an aristocratic woman), or with some type of affiliation with aristocratic circles (as with the old couple from Umezu). Elevation into the aristocracy was seen as a guarantee that newly acquired prosperity would last for several generationseven though by the mid-Muromachi period, the aristocracy was generally impoverished and could not compete with the wealthiest merchants and the most powerful daimyo. The symbolic role of the aristocracy probably is an indication of the authorship of these stories, which were composed, as Komatsu Kazuhiko suggests, by priests and impoverished nobles. ${ }^{42}$ On the other hand, we should also note

${ }^{42}$ Komatsu, Fuku no kami to binbōgami, 35. 
that many professional guilds exercised their activities protected by official court titles and affiliations; in this sense, at least, these stories also reflect one aspect of later medieval social and economic reality.

In all these stories, one also notices the apparent coexistence of two different economic modes: one is quasi-capitalist, and the other is one of subsistence tempered by magic. In the first mode, proper to temples and shrines and aristocratic families envisioned as centers of stable wealth, the accumulation of capital is done for the sake of its reproduction; this mode remains in the background of the stories and is never discussed in depth or problematized. The second mode is essentially non-capitalist: it presupposes a subsistence economy, in which the acquisition of wealth can only be explained through divine intervention as retribution of merit. If the protagonists of these stories are able to keep up the mechanism of sacred economy (meritwealth-offerings-merit-wealth-offerings etc.), they will be able to join the ranks of quasi-capitalist social groups. If they fail to do so, they will return to the realm of subsistence and poverty. Even so, the quasi-capitalist mode tends to be temperate, at least according to our contemporary standards. For example, accumulation is potentially infinite, but infinite wealth is never sought for; wish-fulfilling jewels and magical hammers are almost never used, and when they are, it is always for limited goals. Indeed, the acquisition of infinite wealth is almost unthinkable in this context-a grotesque manifestation of greed, rather than the fulfillment of a divine promise. Instead, the goal in most stories seems to be the protagonists' co-optation into the aristocracy and, therefore, into the realm of stable wealth. This general attitude changed during the Tokugawa era, when merchants' greed came to be emphasized and openly criticized (as we will see below).

Let us now consider more in detail the role of religious institutions in the production of wealth. The case of the ascetic Myōren in the Shigisan engi is interesting because it summarizes several aspects of religious intervention in the economic arena according to the medieval Japanese imaginary. In the first scroll (and in other versions of the story), Myōren is the agent behind the accumulation of wealth by the choja. As such, he benefits from the latter's wealth through the daily donations he receives. When the choja's family breaks the original contract, Myōren makes further profits from 
the chojja's storehouse. The other episodes of the painted scroll deal more directly with the symbolic capital accumulated by Myōren. The second story tells how Myōren has become famous at court because of the miracle of the flying bowl and is requested to perform a ritual to heal Emperor Daigo 醍醐天皇; he succeeds, and presumably gains further symbolic (and material) capital. Finally, the third story tells how, many years after the death of the ascetic, the remains of the storehouse flown to Mt. Shigi by Myōren's bowl are still endowed with miraculous power, and those who collect a splinter of wood from what is left of the structure will acquire wealth.

Other stories present a less indirect, but still very concrete, intervention of religious institutions in the production of wealth: they describe rituals at temples and shrines and religious objects such as talismans and amulets sold in temples. In these cases, people's hopes for wealth generated an economy of religious commodities (goods and services); moreover, wealth was always the result of religious faith and devotion, and the acceptance of religiously and politically authorized social norms. The role of religious institutions was thus very important, ranging from providing background moral codes to specific ritual services to the circulation of symbolic capital and goods.

More theoretically, these stories present religious institutions as mediators in exchange processes taking place between the visible world and the invisible realm of divinities and spirits. Temples were like investment banks: they identify where to invest (a deity, a ritual, an object, etc.) and how much (the amount of the offering), manage the investments (through ritual activity), and distribute the profits (salvation and/or worldly benefits). We could summarize the process as follows: the donor gives offerings to a priest or a religious institution, which in turn gives it to the buddhas or kami; in retribution, the divinities bestow wealth and success upon the donor. The donor has the obligation to give back part of his newly acquired wealth as a sign of gratitude; if he or she fails to do so, they will lose everything. It is interesting to note that this process of generation of wealth as described in popular narratives is essentially similar to actual economic processes taking place at temples and shrines, especially those concerning interests on loans (jöbun) and fees, as discussed above. 


\section{Wealth, Power, and Resistance}

A significant portion of economic practices in medieval Japan was carried out by members of specific groups, known as jinin (lit., 'people of the kami') and yoriudo or shuto 毷徒, the lower members of the religious hierarchy at shrines and temples, respectively, and by itinerant religious specialists such as yamabushi, hijiri, and oshi (or onshi). ${ }^{43}$

Yoriudo and jinin were typical figures created by medieval Buddho-Shinto institutions in order to support their attempt to impose some kind of hegemony over their vast and scattered land possessions and economic interests. Yoriudo and jinin usually came from the upper stratum of the peasantry (byakushō 百姓). They entrusted their lands to religious institutions, and in exchange received several benefits: they controlled and supervised agricultural labor and production; were involved in transportation, commerce, and loans; and secured the capital necessary for building and rebuilding temples, sacred objects, and the performance of rituals. They were also technicians, responsible for engineering works (dams, field terracing) that improved agricultural production. At times, they were also employed as a sort of police/military corps of temples and shrines. Thus, the jinin were responsible for economic developments in religious estates, and at the same time they were the defenders of the social and economic order.

The jinin were not only concerned with production, technology, art, or coercion; they also attempted to create social consent in the estates (shoen 荘園), as a way to ensure a higher docility and more efficiency in social control and economic production. For example, when a large religious institution from the Nara-Kyoto area acquired a new estate, jinin and/or yoriudo were dispatched there and built a new temple or worship hall (as a branch of the main temple in

43 There is an extensive literature on these figures in Japanese scholarship, and a growing information in other languages as well. My reconstruction here is mostly based on Amino, Nihon chüsei no hyakushō to shokunōmin, especially pages 259-333; and Kuroda, Jisha seiryoku, 159-64. 
the capital) and a new shrine (a branch of the temple's protector's shrine). Then, they explained to the residents the relation between their local deity and the new deities on the basis of the fundamental principle of medieval Japanese Buddhism, according to which Japanese kami were local manifestations of specific buddhas and bodhisattvas (a principle known as honji suijaku 本地垂迹, lit. 'original ground and its manifest traces'). The jinin also developed and organized public events and rituals, such as the ta-asobi 田遊び ('ricefield plays', festivals that took place in the countryside at New Year's or during planting season). These new rituals were instrumental in the creation of a sense of community and hierarchy in the locale by connecting it with more general orders of significance: the region, the network of the main temple, Japan, and finally the entire cosmos. In this way, a cosmic order was superimposed to a local hierarchy (in a way not dissimilar from what already happened at court); by participating in the ritual everyone knew their own position not only in the shoen but also in the entire cosmos. ${ }^{44}$

What I am suggesting here is that jinin and yoriudo (and bijiri, yamabushi, oshi, and other itinerant specialists) were the main protagonists of the attempt to establish a sort of Buddho-Shinto hegemony in medieval Japan; they could even be assimilated to what Antonio Gramsci called 'organic intellectual'-people directly responsible for establishing the hegemony of a certain ruling bloc. The jinin were not just imposing alien ideas and rituals of domination to newly acquired estates in far-flung locales. Themselves people from the low-middle classes, but at the same time unstable allied with major temples that were controlled by the aristocracy and the leading samurai families, the jinin were responsible for the negotiation of values among various social groups and interests which produced a veritable hegemony. They played an important role in the formation and development of economic ideas and practices in medieval Japan, mediating between doctrinal discourses (which usually do not provide specific managerial instructions) and popular practices (such as the hatsubo system).

\footnotetext{
44 See Satō, 'Wrathful Deities and Saving Deities'.
} 
Religious institutions thus were the ultimate guarantors of economic profit and wealth, envisioned as manifestations of the benevolence of the deities and, therefore, signs of future salvation. At the same time, devout people were encouraged to provide economic support to religious institutions in exchange for wealth and salvation. It was a full-fledged system of exchange, in which worldly wealth was exchanged for supernatural protection and benefits, which in turns generated additional worldly wealth. For example, in 1498 the residents of the estate (shōen) of Ikaruga (Harima, in present-day Hyōgo prefecture), belonging to the Hōryūji, afflicted by an invasion of insects, asked the temple for help; the priests performed the Hyakuza Ninnō Lecture at the temple and distributed talismans in the shoen, and succeeded in eliminating the insects. ${ }^{45}$ Choggen (1121-1206), the bijiri known for his successful fund-raising for the reconstruction of the Tōdaiji, wrote: 'the temple performs rituals (kitō) for the estate, and the estate provides for the temple. ${ }^{36}$ The mediating role of religious institutions, which determines the status of all involved in the religious economy, is explained by a statement attributed to Suwa shrine, according to which its main deity, Suwa Daimyōjin, speaks through the priests (kannushi and öbori) who are its emissaries. ${ }^{47}$ Those who accept this vision of society receive positive retribution (wealth in certain cases and rebirth into paradise for all), whereas those who reject it will be punished by the deities in a terrible and cruel way. For example, Ban'a 鏝阿 (?-1207), ${ }^{48}$ a Shingon monk dedicated to the organization of shoen estates and to religious activities

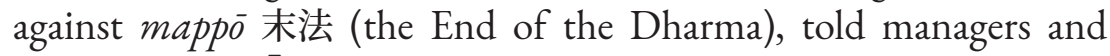
peasants of the Ōta shoen in the province of Higo (present-day Nagasaki prefecture) that the cultivation of newly reclaimed lands and the payment of annual taxes to the temple were the best deeds to be performed in order to acquire merit; however, should they not obey the orders of the temple officers, they would receive punishment from all

\footnotetext{
45 Abe and Ōta, eds., Harima no kuni Ikaruga-shō shiryō, 24.

46 Kamakura ibun, vol. 2, no. 621, 45-46.

47 Azumakagami, vol. 1, 247.

48 On Ban’a, see Mikkyō Daijiten, 1826 b-c.
} 
buddhas, all kami, and even from the saint Kōbō Daishi. ${ }^{49}$ Chōgen again wrote in a document addressed in 1192 to the managers and peasants of a shoen belonging to the Tödaiji that the enemies of the temple 'will become lepers in the present life, and will fall into the Uninterrupted Hell in the next. ${ }^{50}$ Monks performed official rituals of witchcraft and black magic (juso 呪詛) against those who did not comply with the economic or political rules of religious institutions. ${ }^{51}$ Again, it is interesting to note the extent to which economic practices and social ideology where connected to soteriology; it is also remarkable that the interlocking of these religious and economic discourses continued for centuries.

At this point we should ask ourselves what was the actual efficacy of the religious ideology connecting work, wealth, and salvation. Did everyone accept it at face value? Or do we see instances of rebellion and skepticism? Some people chose indeed to reject the religious/ economic ideology of the main temples. The various forms of refusal to worship the local deities, known as jingi fubai 神祇不据, an important feature of the system of domination of the shoen manors, as emphasized by Kuroda Toshio 黒田俊雄, Taira Masayuki 平雅之, and Satō Hiroo, were not animated only by a new form of spirituality, but were challenging at the roots the system of domination of the main temples. Many land stewards (jitō), in particular, seemed to subscribe to the jingi fubai positions: they openly questioned the sacredness of the temple lands and tried to capture the profits they generated. ${ }^{52}$

Many people in the provinces also seem to have questioned the association between wealth and virtue proposed by religious institutions. Several popular legends concerning the murder of strangers

49 Kamakura ibun vol. 2, no. 575, 3-5.

50 Kamakura ibun, vol. 2, no. 621, 45-46.

51 See Rambelli, 'Buddha's Wrath'.

52 On the phenomenon of jingi fubai, see Rambelli, "Just Behave as You Like"'; Kuroda Toshio, Nihon chüsei no kokka to shükyō, especially pages 257-62; and Satō Hiroo, Nibon chūsei no kokka to bukkyō, 89-109; Kami, hotoke, ōken no chüsei, 89-177; Kishömon no seishinshi, 148-82. 
visiting remote villages (a genre known as ijingoroshi異人殺し), which flourished during the Edo period, have an economic meaning. ${ }^{53}$ They explain the sudden wealth of members of the village community as a result of the appropriation of gold and other valuables taken from murdered strangers. These strangers were often itinerant priests or yamabushi who brought to the isolated village Buddhist ideas and practices and different visions of society-visions that were in a way or another authorized by the bakufu and the religious institutions. Murder stories reveal a spirit of resistance against the political and religious establishments and the translocal economy they supported. In these narratives, wealth is often the result of interference from the outside world, the consequence of a crime, something that disrupts the traditional life of the village. Furthermore, Carmen Blacker describes how traditional village society criticizes sudden wealth, often a feature of newcomers to the village, and ostracizes its holders, by attributing it to black magic such as the manipulation of foxes and badgers, who take away vital energy and wealth from the other villagers. ${ }^{54}$

A well-known story for the Edo period, entitled 'Nakano chōja' (The wealthy man from Nakano), exemplifies a number of these elements. A merchant became rich with his trade in horses, and gave most of his profits to the bodhisattva Kannon at Sensōji 浅草寺. As retribution, one day he found a big pot full of gold coins under the floor of his house. He became overly attached to that gold; he turned greedy and stingy, and gold kept accumulating. In order to protect his new wealth, he decided to bury the gold in the woods, then he killed all the servants who had helped him in order to keep secret the treasure's location. However, one day, at the eve of his daughter's long-awaited marriage ceremony, the girl is abducted by the spirits of the murdered servants, turns into a snake, and kills herself in a pond. This story is an Edo period version of an earlier, Muromachi period narrative, inspired by a real person, Suzuki Kurō (1371-1440), known for his piety and generosity. The Edo period version focuses on the death of the protagonist's daughter (apparently a real event)

\footnotetext{
53 Komatsu, Ijinron: Minzoku shakai no shinsei.

54 Blacker, The Catalpa Bow.
} 
and seems to question the medieval logic of wealth as retribution for good behavior. If Suzuki was so pious, the anonymous author seems to wonder, how could his beloved daughter die? There must be a hidden dimension to the events, envisioned as abnormal attachment to wealth that generates murder, which is turn compensated karmically by the death of a beloved person.

In other words, we see in these later stories attempts to describe the workings of capitalism within a pre-capitalist, static society. Wealth is no longer the result of piety, but the consequence of a crime that corrupts people and haunts their communities. Often represented by money (as opposed to land or rice), wealth now comes from the outside and disrupts old traditions and ways of life. It concentrates in a few individuals, depriving the majority of the villagers of their meager income. In other words, whereas a few grew richer, the majority becomes poorer. It is interesting to note that such a new cultural situation is often dealt by traditional societies in religious terms-as the result of black magic or the intervention of some evil supernatural entity, in a situation analogous to the one described by Michael Taussig in modern South America. ${ }^{55}$ We could also see these later, Edo period stories, as belonging to a different discourse, in which Buddho-Shinto divinities and their institutions are no longer in charge of controlling the bestowal of wealth; rather, wealth is seen as a negative force coming from greed, murder, and black magic. This vision is in stark contrast with the typical understanding, according to which wealth results from merit-making (moral actions) and is bestowed by gods (often, the seven gods of good fortune or shichifukujin) in a sort of cargo-cult. ${ }^{56}$

\section{Concluding Remarks on the Buddho-Shinto General Economy}

By now it should be clear that religious institutions controlled, more or less directly, an enormous amount of wealth. Part of it was

\footnotetext{
55 Taussig, The Devil and Commodity Fetishism in South America.

56 See Rambelli, 'Sea Theologies'.
} 
reinvested and kept circulating (suiko, kashiage, shidosen, etc.), but another part was 'unproductive': used in countless rituals, consumed to maintain temples and clergy, stored away in the form of precious objects without clear market value. Represented in this way, the medieval Buddhist economy does not seem to respond to any economic rationale. This is a case of what Georges Bataille called 'general economy', whose primary object is 'the "expenditure" (the "consumption") of wealth, rather than production. ${ }^{.57}$

The general economy of religious institutions was based on several orders of offerings gravitating, as we have seen, around the 'superior portions' (jöbun) - the symbolic core of the entire system. The superior portions were donated (extorted?) in order to be eliminated from the secular market, an enormous mass of capital, accumulated by religious institutions and in part destroyed through ritual transfer to the invisible world of buddhas and kami. In this respect it follows the description provided by Georges Bataille. However, we find two important differences: first of all, not all the surplus collected by religious institutions was destroyed; a certain amount of it was actually returned to the secular market as loans with the ultimate goal to increase the yield of religious profits-ideally, the more religious institutions loaned, the more they would acquire in an endless escalation of surplus and expenditure. Secondly, profit was infused back in society as wages for professionals and laborers and purchases for the temples and their residents. Rather than with an 'accursed share', Buddhist general economy seems to be dealing with a 'blessed share'-whose expenditure would result in higher productivity and widespread wealth. ${ }^{58}$

Such expenditure was utilized to secure/display the incessant intervention of deities in the realm of production. Agricultural harvest,

\footnotetext{
57 Bataille, The Accursed Share, vol. 1, 9.

58 This is indeed the argument proposed in the early Meiji period by maverick activist monk Sada Kaiseki (1818-1882) in his discussion of the positive economic role of temples for the society at large. See Rambelli, 'Sada Kaiseki: An Alternative Discourse on Buddhism, Modernity, and Nationalism in the Early Meiji Period'.
} 
industrial products, fish and meat were conceptualized as the result of the sacred power of the 'first produce' of various kinds loaned to the producers by religious institutions. In this way, economic yield and surplus were explained in religious terms and religious institutions were able to play an important role in the economy and everyday activities of medieval Japanese society. In other words, the very presence of sacred surplus was used, in a circular, paradoxical way, to justify the existence of religious institutions managing/destroying it. I would like to propose a number of functions played by the wealth accumulated by religious institutions-and a more sustained and systematic investigation will probably identify more.

1. Economic functions: construction and maintenance of temples, shrines, statues, and ritual objects, honoraria for religious professionals for their ritual services, salaries for menial workers in the temples, etc. generated an economic field of sizeable proportions: jobs, whose salaries generated purchases, and therefore trade, production, etc. This factor should not be underestimated. In addition, even apparently 'unproductive' offerings consumed in rituals were actually thought to result in higher productivity-a small investment for a great profit (as described by the Shinnyokan and other medieval texts). Offerings were also given in exchange for certain services of various nature, among which ritual help to improve production (prayers, rain-making and insect-chasing ceremonies, etc.)

2. Soteriological functions: offerings in general were described as generating great profits for the donors, ranging from worldly benefits (genze riyaku) to rebirth in paradise and becoming buddha in this very body. This interpretation of offerings was in accord with well-established doctrines about the dynamics of merit-making, in which worldly wealth was converted into spiritual cash, which could in turn be used in many ways, among which the generation of new worldly wealth.

3. Functions related to power and symbolic capital: wealth accumulated by religious institutions was related in varying 
proportions to social domination and to the formation of 'symbolic capital', in Pierre Bourdieu's term. Up to a certain extent, the more the wealth accumulated, the more the symbolic capital gained, and vice-versa, in an incessant process. The circuit of symbolic capital is a paradoxical site: without such symbolic capital, religious institutions cannot impose their economic vision on society; but without their control over society they cannot acquire symbolic capital. As Michel de Certeau wrote, 'The credibility of a discourse is what first makes believers act in accord with it. It produces practitioners. To make people believe is to make them act. But, by a curious circularity, the ability to make people act [...] is precisely what makes people believe. ${ }^{59}$ This circular movement between power, wealth, and prestige could explain phases of prosperity and decay of temples and shrines. Some cultic sites could have had great symbolic capital but little wealth and power; the opposite might have happened as well. In some periods they were able to synchronize symbolic capital and power, and therefore to exercise a major impact on medieval society. Symbolic capital was also acquired by the donors, as participant in a higher order, members of a productive/salvific covenant with the deities. The combination of these three functions was at the basis of the general economy of Buddhist institutions in medieval Japan.

Now, to go back to the original question of this chapter, namely, whether a Buddhist economic theory and practice exist, we can highlight the following points:

1. Large Buddhist temples were/are economic hubs

2. In its social dimension, Buddhism focused on merit-making rather than on renunciation, and envisioned merit as a form of capital. Not only that: labor was understood as a devo-

59 De Certeau, The Practice of Everyday Life, vol. 1, 148. 
tional activity that generates merit. Representations of this principle can be found in numerous ritual manuals for professions composed in medieval and early-modern Japan, ${ }^{60}$ and in more explicit formulations, in Edo period Buddhist texts, most notably by Suzuki Shōsan 鈴木正三 in Banmin tokuyō 万民徳用.

3. The proliferation of discourses and rituals about labor, production, and wealth acquisition can perhaps be understood as attempts to counter the proto-capitalist mode of production and the labor alienation that came with it

4. The crucial role of divinities: the agents of value production and wealth generation were not only buddhas and bodhisattvas but also and especially kami-in particular, vernacular gods (Ebisu, Daikoku, Konpira, Shichifukujin, Inari, etc); even when buddhas and bodhisattvas are the protagonists of stories about wealth, they act like kami. This is an important aspect of the amalgamation process between Buddhism and local cults (which later became Shinto as an autonomous religious tradition) that characterizes premodern Japan, and especially the medieval period: it amounts to co-opting the local gods to serve as economic agents in ways that normative Buddhist divinities cannot.

While the general premises and the conceptual framework showed a remarkable stability over a long time (from the early Heian period to the late Tokugawa period), in terms of the idea that morally adequate behavior would result in economic benefits, we also notice significant shifts. This first shift is the transition, in the explanations for economic success, from a focus on karma as abstract and impersonal processes to the direct intervention of divinities-especially Buddhist-Shinto combinatory gods which were ultimately systematized in the seven gods of fortune (shichifukujin). The second shift

60 See Rambelli, 'Honji Suijaku at Work'; Buddhist Materiality. 
is the redefinition of wealth $(t o m i)$ as fortune $(f u k u)$ resulting from merit/virtue (toku). In both cases, the transition is from abstract agencies (karma) and virtues (merit) to concrete entities (gods, often manifesting themselves in human form), objects (gold, riches) and social relations (social ascent, etc.). The third shift occurred in the Tokugawa period, when competing economic discourses proliferate. Whereas post-medieval Buddhist ideas and narrative models continued to circulate, new anti-Buddhist formulations also emerged, which questioned the understanding of wealth as a divine gift from Buddhist divinities (and, in some cases, even the role of divinities in the economy). All these transitions are related to changes in Japanese religiosity, a further proof of the deep connections between religion and economic in premodern Japan.

\section{Bibliography}

\section{Primary Sources}

Azuma kagami 吾妻鏡 [Mirror of the Eastern Regions of Japan]. In Azuma kagami 吾妻鏡, 2 vols. Kokushi taikei 国史大系 [National History Series] volumes 32-33. Tokyo: Yoshikawa Kōbunkan 吉川弘文館, 2004.

Banmin tokuyō 万民徳用 [The Virtues of All the People]. By Suzuki Shōsan 鈴木正三. In Kana hōgoshū 仮名法語集 [Collection of Buddhist Sermons in the Vernacular], edited by Miyasaka Yushō 宮坂宥勝, 262-79. Nihon koten bungaku taikei 日本古典文学 大系 [Japanese Classical Literature Series] volume 83. Tokyo: Iwanami Shoten 岩波書店, 1964.

Daikoku mai 大黒舞 [The Dance of the God Daikoku]. In

Muromachi monogatarish $\bar{u}$ 室町物語集 [Collected Tales from the Muromachi Period] vol. 2, 55-84. Shin Nihon koten bungaku taikei 新日本古典文学大系 [New Japanese Classical Literature Series] volume 55. Tokyo: Iwanami Shoten 岩波書店, 1996. Kamakura ibun 鎌倉遺文 [Miscellaneous Documents from the Kamakura Period], 52 vols. Edited by Takeuchi Rizō 竹内理三. Tokyo: Tōkyōdō Shuppan 東京堂出版, 1971-1997. 
Kohon setsuwashū 古本説話集 [Collected Tales from Old

Manuscripts]. Edited by Takahashi Mitsugu 高橋貢. 2 volumes.

Kōdansha gakujutsu bunko 講談社学術文庫 [Kōdansha

Academic Pocket Book Series]. Tokyo: Kōdansha 講談社, 2001.

Konjaku monogatarishü 今昔物語集 [Collected Tales from the Past

and the Present]. In Yamada Yoshio 山田孝雄 et al., eds., Konjaku

monogatarish $\bar{u} .5$ vols. Nihon koten bungaku taikei 日本古典

文学大系 [Japanese Classical Literature Series] volumes 22-26.

Tokyo: Iwanami Shoten 岩波書店, 1963.

Mikkyō daijiten 密教大辞典 [Great Encyclopedia of Esoteric

Buddhism]. Edited by Mikkyō daijiten hensankai 密教大辞典

編纂会, 1931. Revised edition by Chishakuin Daigaku Mikkyō

Gakkainai Mikkyō daijiten saihan iinkai 智積院大学密教学会内

密教大辞典再版委員会. Kyoto: Hōzōkan 法蔵館, 1970. Reduced size reprint, 1983.

Nyoi hōju tenrin bimitsu genshin jōbutsu kinrin juō kyō 如意宝珠

転輪秘密現身成仏金輪呪王経 [Sutra of the King of Spells of the Metal Ring on the Wish-Fulfilling Jewel for Turning the Wheel (of Dharma) and for the Esoteric Becoming Buddha in the Present Body]. In Taishō shinshū Daizōkyō 大正新脩大蔵経 [Taisho New Edition of the Buddhist Canon] vol. 19, no. 961: 330b-334c.

Shigisan engi 信貴山縁起 [Origin Stories of Mt. Shigi]. In Jisha eng $i$ 寺社縁起 [Origin Stories of Buddhist Temples and Shinto Shrines], edited by Sakurai Tokutarō et al., 23-28. Nihon shisō taikei 日本思想体系 [Japanese Thought Series], volume 20. Tōkyō: Iwanami Shoten 岩波書店, 1975.

Shinnyokan 真如観 [Contemplation of Suchness]. In Tendai bongaku-ron 天台本覚論 [Tendai Original Enlightenment Texts], edited by Tada Kōryū 多田厚隆 et al., 119-49. Nihon shisō taikei 日本思想体系 [Japanese Thought Series], volume 9. Tokyo: Iwanami Shoten 岩波書店, 1973.

Shōyoshō 聖誉抄 [Notes by (Monk) Shōyo (on the Life of Prince Shōtoku)]. In Hōryūji shiryō shūsei 法隆寺史料集成 [Collection of Documents from Hōryūji]], volume 10, edited by Hōryūji Shōwa shizaichō hensanjo 法隆寺昭和資材帳編纂所. Tokyo: Wakō Bijutsu Shuppan ワコ-美術出版, 1985. 
Uji shūi monogatari 宇治拾遺物語 [Collected Tales from Uji]. In Uji shüi monogatari, Kobon setsuwa-shū 宇治拾遺物語・広本説話集 [Collected Tales from Uji, Collected Tales-Extended Version]. Shin Nihon koten bungaku taikei 新日本古典文学大系 [New Japanese Classical Literature Series], volume 42. Tokyo: Iwanami Shoten 岩波書店, 1996.

Umezu no choja monogatari 梅津の長者物語 [The Tale of the Wealthy Man from Umezu]. In Muromachi jidai monogatari taisei 室町時代物語大成 [Collection of Tales from the Muromachi Period], volume 5, edited by Yokoyama Shigeru 横 山重 and Matsumoto Takanobu 松本隆信. Tokyo: Kadokawa Shoten 角川書店, 1973-1988.

\section{Secondary Sources}

Abe Takeshi 阿部猛, and Ōta Junzō 太田順三, eds. Harima no kuni Ikaruga-shō shiryō 播磨国鵤荘資料 [Documents from the Ikaruga Landholding in Harima Province]. Tokyo: Aoki Shoten 青木書店, 1970 .

Amino Yoshihiko 網野善彦. Muen, kugai, raku: Nibon chüsei no jiyū to heiwa 無縁·公界・楽一日本中世の自由と平和 [Social NonAttachment, Open Spaces, Free Market Areas: Freedom and Peace in Medieval Japan]. Tokyo: Heibonsha 平凡社, 1996.

———. Nibon chüsei ni nani ga okita ka 日本中世になにが起きた か [What Happened in Medieval Japan?]]. Tokyo: Nihon Editā Sukūru Shuppanbu 日本エディタースクール出版部, 1997.

——_. Nihon chūsei no byakushō to shokunōmin 日本中世の百姓 と職能民 [Peasants and the Professionals in Medieval Japan]. Tokyo: Heibonsha 平凡社, 1998.

Bataille, Georges. The Accursed Share. New York: Zone Books, 1989. Blacker, Carmen. The Catalpa Bow: A Study of Shamanistic Practices in Japan. London: George Allen and Unwin, 1986.

Collins, Steven. Nirvana and Other Buddhist Felicities. Cambridge: Cambridge University Press, 1998.

de Certeau, Michel. The Practice of Everyday Life. Vol. 1. Berkeley:

University of California Press, 1988.

Gernet, Jacques. Buddhism in Chinese Society: An Economic History 
from the Fifth to the Tenth Centuries. New York: Columbia University Press, 1995.

Ishimoda Shō 石母田正. Nibon no kodai kokka 日本の古代国家

[The Ancient Japanese State]. Tokyo: Iwanami Shoten 岩波書店, 2017.

Iwai Katsuhito 岩井克人. Shihonshugi wo kataru 資本主義を語る

[Discussing Capitalism]. Tokyo: Kōdansha 講談社, 1994.

Kasamatsu Hiroshi 笠松宏至. 'Butsuda senyū no chi kuikaeshibekarazu' 仏陀施入之地不可悔返 [Land Donated to the Buddha Cannot Be Claimed Back by Humans]. Shigaku zasshi 史学雑誌 [Historiography Journal] 80, no. 7 (1971): 35-45.

- _ _. 'Butsumotsu, sōmotsu, ninmotsu' 伀物・僧物・人物

[Properties of the Buddha, Properties of the Samgha, Human Properties]. Shisō思想 [Thought] 670 (1980), 26-38.

Katsumata Shizuo 勝俣鎮夫. 'Baibai, shichiire to shoyū kannen' 売 買・質入れと所有観念 [Commercial Transactions, Pawns, and the Concept of Ownership]. In Futan to zoyo 負担と贈与 [Payments and Gifts], edited by Yamaguchi Keiji 山口啓二, 93-116. Series

Nihon no shakaishi 日本の社会史 [Social History of Japan], volume 4. Tokyo: Iwanami Shoten 岩波書店, 1994.

Ketelaar, James E. Of Heretics and Martyrs in Meiji Japan:

Buddhism and Its Persecution. Princeton: Princeton University Press, 1990.

Komatsu Kazuhiko 小松和彦. Fuku no kami to binboggami 福の神と 貧乏神 [Gods of Wealth and Gods of Poverty]. Tokyo: Chikuma Shobō 筑摩書房, 1998.

- - - Ijinron: Minzoku shakai no shinsei 異人論一民俗社会の心性 [Strangers: Mentalities of Folk Society]. Tokyo: Seidosha 青土社, 1985.

Komatsu Kazuhiko 小松和彦, and Kurimoto Shin’ichirō 栗本慎 一郎. Keizai no tanjo 経済の誕生 [The Birth of the Economy]. Tokyo: Kōsakusha 工作舎, 1982.

Kuroda Toshio 黒田俊雄. Jish a seiryoku 寺社勢力 [The Power of Religious Institutions]. Tokyo: Iwanami Shoten 岩波書店, 1980. - - - Nihon chüsei no kokka to shūkyō 日本中世の国家と宗教 [State and Religion in Medieval Japan]. Tokyo: Iwanami Shoten 岩波書店, 1975 . 
Le Goff, Jacques. Your Money of Your Life: Economy and Religion in the Middle Age. New York: Zone Books, 1988.

Miyata Noboru 宮田登, ed. Shichifukujin shinkōjiten 七福神信仰 事典 [Encyclopedia of the Cults of the Seven Gods of Fortune]. Tokyo: Ebisu Kōshō Shuppan 戎光祥出版, 1998.

Nakamura, Kyōko Motomachi. Miraculous Stories from the Buddhist Tradition: The Nihon Ryōiki of the Monk Kyokkai. Cambridge: Harvard University Press, 1973.

Nakazawa Shin'ichi 中沢新一. Akutōteki shikōo 悪党的思考 [Rogue Thought]. Tokyo: Heibonsha 平凡社, 1988.

Oda Yūzō 小田雄三. 'Kodai-chūsei no suiko'古代•中世の出挙

[Suiko Loans in Ancient and Medieval Japan]. In Futan to zōyo 負担と贈与 [Payments and Gifts], edited by Yamaguchi Keiji 山口 啓二, 93-116. Nihon no shakaishi 日本の社会史 [Social History of Japan], vol. 4. Tokyo: Iwanami Shoten 岩波書店, 1986.

Rambelli, Fabio. Buddhist Materiality, A Cultural History of Objects in Japanese Buddhism. Stanford, CA: Stanford University Press, 2007.

- - . 'Buddha's Wrath: Esoteric Buddhism and the Discourse of Divine Punishment'. Japanese Religions 27 no. 1 (2002): 41-68.

- - - 'Honji Suijaku at Work: Religion, Economics, and Ideology in Pre-modern Japan'. In Buddhas and Kami in Japan: Honji Suijaku as a Religious Paradigm, edited by Mark Teeuwen and Fabio Rambelli, 255-86. London: Routledge, 2003.

- - . "Just Behave as You Like": Radical Amida Cults and Popular Religiosity in Premodern Japan'. In Approaching the Land of Bliss: Religious Praxis in the Cult of Amitabha, edited by Richard K. Payne and Kenneth K. Tanaka, 169-201. Honolulu: University of Hawai'i Press, 2004.

_- - ' 'Sada Kaiseki: An Alternative Discourse on Buddhism, Modernity, and Nationalism in the Early Meiji Period'. In Politics and Religion in Japan: Red Sun, White Lotus, edited by Roy Starrs, 104-42. London: Palgrave MacMillan, 2011.

- _- 'Sea Theologies: Elements for a Conceptualization of Maritime Religiosity in Japan'. In The Sea and the Sacred in Japan: Aspects of Maritime Religion, edited by Fabio Rambelli, 181-99. London: Bloomsbury, 2018. 
- _- 'The Vicissitudes of the Mahāsammata in East Asia: The Buddhist Origin Myth of Kingship and Echoes of a Republican Imagination'. Medieval History Journal 17, no. 2 (2014): 1-21.

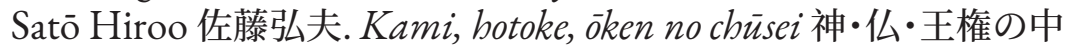
世 [Gods, Buddhas, and Kingship in Medieval Japan]. Kyoto: Hōzōkan 法蔵館, 1998.

- - K Kishōmon no seishinshi 起請文の精神史 [Intellectual History of Oaths]. Tokyo: Kōdansha 講談社, 2006.

- - - Nibon chüsei no kokka to bukkyō 日本中世の国家と仏教 [State and Buddhism in Medieval Japan]. Tokyo: Yoshikawa Kōbunkan 吉川弘文館, 1987.

- - - 'Wrathful Deities and Saving Deities'. In Buddhas and Kami in Japan: Honji Suijaku as a Religious Paradigm, edited by Mark Teeuwen and Fabio Rambelli, 95-114. London: Routledge, 2003.

Stone, Jacqueline I. 'The Contemplation of Suchness'. In Religions of Japan in Practice, edited by George J. Tanabe, Jr., 199-206. Princeton: Princeton University Press, 1999.

Taussig, Michael. The Devil and Commodity Fetishism in South America. Chapel Hill: University of North Carolina Press, 1980. Teeuwen, Mark, and Fabio Rambelli, eds. Buddhas and Kami in Japan: Honji Suijaku as a Religious Paradigm. London and New York: Routledge, 2003. 